\title{
THE "CONTROLLING PERSONS" LIABILITY OF BROKER-DEALERS FOR THEIR EIMPLOYEES' FEDERAL SECURITIES VIOLATIONS
}

The Securities Act of $1933^{1}$ and the Securities Exchange Act of $1934^{2}$ give the investor various expansive civil remedies against deceitful securities underwriters, ${ }^{3}$ offerors and sellers. ${ }^{4}$ Armed with these broad causes of action, private investors would appear to be wellprotected against the fraudulent acts of securities salesmen. In many situations, however, an action against the wrongdoing salesman may be fruitless. Since salesmen usually have only limited financial resources, the injured investor will generally prefer to sue the party with the "deepest pockets," the party most able to bear the loss. Moreover, when named as defendants in a securities fraud suit, salesmen often find it convenient to disappear, leaving the plaintiff with, at most, an unsatisfied default judgment. ${ }^{5}$ Thus, the defrauded investor almost

1. 15 U.S.C. $\$ \S 77 \mathrm{a}$-aa (1970). NOTE:

HEREAFTER THE FOLLOWING CITATIONS WLL BE USED IN THIS

A. Bromberg, Securities LAw: FraUd-SEC RuLe 10b-5 (1973) Thereinafter cited as BROMBERG];

Ruder, Multiple Defendants in Securities Law Fraud Cases: Aiding and Abetting, Conspiracy, In Pari Delicto, Indemnification, and Contribution, 120 U. PA. L. Rev. 597 (1972) Thereinafter cited as Ruder].

2. 15 U.S.C. $\$ \S 78 \mathrm{a}-\mathrm{jj}(1970)$.

3. See section 11 of the 1933 Act, 15 U.S.C. $\& 77 \mathrm{k}$ (1970) (subjecting an underwriter to liability for damages rcsulting from material misrepresentations or omissions in registration statements).

The term "underwriter" has been broadly defined to include anyone who directly or indirectly participates in the distribution of securities from an issuer to the public. SEC v. Spectrum, Ltd., 489 F.2d 535, 541 n.11 (2d Cir. 1973); SEC v. North Am. Researcli \& Dev. Corp., 424 F.2d 63, 72 (2d Cir. 1970).

4. See, e.g., section 12(1) of the 1933 Act, 15 U.S.C. $\$ 77 l(1)$ (1970) (making any offeror or seller of securities who violates the registration requirement hable to persons purchasing such securities from him); § 12(2), 15 U.S.C. \& 77l(2) (1970) (making a person offermg or selling securities by the use of false or misleading stateinents liable to the purchaser of such securities); $\$ 9$ (e) of the 1934 Act, 15 U.S.C. $\$ 78 \mathrm{i}(\mathrm{e})$ (1970) (providing a cause of action for investors injured by the manipulation of securities histed on a national securities exchange).

In addition to these explicit liability sections, investors have been given an important implied cause of action under section 10(b) of the 1934 Act, 15 U.S.C. $\$ 78$ j(b) (1970), and rule 10b-5, 17 C.F.R. $\$ 240.10 b-5$ (1973) (prohibiting material misstatements or omissions in connection with the purchase or sale of any security). Sec Surperintendent of Ins. v. Bankers Life \& Cas. Co., 404 U.S. 6, 13 n.9 (1971).

5. See, e.g., Kamen \& Co. v. Paul H. Aschkar \& Co., 382 F.2d 689 (9th Cir. 1967), cert. dismissed, 393 U.S. 801 (1968); Goodman v. H. Hentz \& Co., 265 F. 
invariably prefers to proceed against the salesman's employer: the brokerage house itself and its partners or officers and directors. ${ }^{6}$

Although the courts generally have permitted injured investors to recover from brokerage firms for the federal securities violations of their salesmen, no uniform or consistent theory has been utilized to justify such a cause of action. The theories employed range from the accepted and conventional-liability imposed on a brokerage house as an "aider and abettor" of an employee's federal securities violation ${ }^{7}$ - to the novel and unique-implied private causes of action under the "diligent supervision" rules of the New York Stock Exchange $[\mathrm{NYSE}]^{8}$ and the National Association of Securities Dealers,

Supp. 440 (N.D. IIl. 1967); Lorenz v. Watsou, 258 F. Supp. 724 (E.D. Pa. 1966); cf. SEC v. First Sec. Co., 463 F.2d 981 (7th Cir.), cert. denied, 409 U.S. 880 (1972) (wrongdoing president of brokerage house committed suicide).

6. But see Herring v. Hendison, 218 F. Supp. 419 (S.D.N.Y. 1963), where only the wrongdoing salesman was successfully sued since the brokerage house had folded and a default judgment was entered against its owner.

7. See, e.g., SEC v. First Sec. Co., 463 F.2d 981 (7th Cir.), cert. denied, 409 U.S. 880 (1972); SEC v. Charles A. Morris \& Associates, Inc., [1972-1973 Transfer Binder] CCH FED. SEC. L. REP. IT 93,756 (W.D. Tenn. 1973); Anderson v. Francis I. duPont \& Co., 291 F. Supp. 705 (D. Minn. 1968). See also Landy v. FDIC, 487 F.2d 139 (3d Cir. 1973), cert. denied, 42 U.S.L.W. 3593 (U.S. Apr. 28, 1974) (action against brokerage house for aiding and abetting embezzling bank president); Brennan v. Midwestern United Life Ins. Co., 417 F.2d 147 (7th Cir. 1969), cert. denied, 397 U.S. 989 (1970) (action against corporation for aiding and abetting securities dealer in fraudulent sales of corporation's stock). See generally 2 BROMBERG $§ \S 8.5(530)$ (549).

8. Rule 405 requires every member organization to, inter alia:

(1) Use due diligence to learn the essential facts relative to every customer, every order, every cash or margin account ....

(2) Supervise diligently all accounts handled by registered representatives of the organization.

(3) Specifically approve the opening of an account prior to or promptly after the completion of any transaction for the account of or with a customer ... The member, general partner, officer or designated person approving the opering of the account shall, prior to giving his approval, be personally informed as to the essential facts relative to the customer and to the nature of the proposed account .... Reprinted in 2 CCH N.Y. STOCK ExcH. GUIDE शี 2405 (1970).

The literature on implied actions under the stock excliange rules is extensive. See generally Allen, Liability Under the Securities Exchange Act for Violations of Stock Exchange Rules, 25 Bus. LAw. 1493 (1970); Hoblin, A Stock Broker's Implied Liability to Its Customer for Violation of a Rule of a Registered Stock Exchange, 39 FoRDHAM L. Rev. 253 (1970); Lowenfels, Implied Liabilities Based upon Stock Exchange Rules, 66 ColUM. L. Rev. 12 (1966); MacLean, Brokers' Liability for Violation of Exchange and NASD Rules, 47 DENVER L.J. 63 (1970); Wolfson \& Russo, The Stock Exchange Member: Liability for Violation of Stock Exchange Rules, 58 CALIF. L. Rev. 1120 (1970); Comment, The "Know Your Customer" Rule of the NYSE: Liability of Broker-Dealers Under the UCC and Federal Securities Laws, 1973 DUKB L.J. 489; Note, Private Actions as a Remedy for Violations of Stock Exchange Rules, 83 HARV. L. REV. 825 (1970). 
Inc. [NASD]. ${ }^{9}$ However, neither of these theories is particularly useful to the injured investor, the former because of difficulties of proof ${ }^{10}$ and the latter because of judicial reluctance to create such a cause of action. ${ }^{11}$ Therefore, most investors who wish to sue a brokerage

\section{Section 27 requires each member to:}

(a) [E]stablish, maintain and enforce written procedures which will enable it to supervise properly the activities of each registered representative and associated person....

(b) [D]esignate a partner, officer or manager in each office . . to to carry out the written supervisory procedures . . . .

(c) [R]eview and endorse in writing . . . all transactions and all correspondence of its registered representatives.....

(d) [P]eriodic[ally] examin[e] . . . customer accounts. . . .

(e) [A]scertain by investigation the good character, business repute, qualifications and experience of [employees] .... Reprinted in NATIONAL Association of SECURITIES DEALERS, INC., REPRINT OF THE MANUAL If 2177 (1973).

The NASD rules, regulating member over-the-counter broker-dealers, are promulgated pursuant to section $15 \mathrm{~A}$ of the 1934 Act, 15 U.S.C. $\$ \S 70 o-3(b)$ to (d) (1970). See generally Lowenfels, Private Enforcement in the Over-the-Counter Securities Markets: Implied Liability Based on NASD Rules, 51 CORNELL L.Q. 633 (1966); MacLean, supra note 8; Comment, Civil Liability for Violation of NASD Rules: SEC v. First Securities Co., 121 U. PA. L. Rev. 388 (1972).

10. Traditionally, in order to hold a brokerage firm liable as an aider-abettor a plaintiff has been required to prove both that the brokerage firm knew an illegal act was committed and that the firm rendered substantial assistance to the wrongdoer. See Landy v. FDIC, 486 F.2d 139 (3d Cir. 1973), cert. denied, 94 S. Ct. 1979 (1974); Ruder 638-39. There is, however, some indication that the standard of liability is beiug lowered. See SEC v. First Sec. Co., 463 F.2d 981 (7th Cir.), cert. denied, 409 U.S. 880 (1972) (liability predicated on aiding and abetting may be founded on less than actual knowledge and participation in a 10b-5 violation); cf. SEC v. Spectrum, Ltd., 489 F.2d 535 (2d Cir. 1973) (attorney who negligently rendered an opinion letter stating that securities could be sold without federal registration held liable as aider-abettor in an SEC enforcement proceeding).

11. See, e.g., Colonial Realty Corp. v. Bache \& Co., 358 F.2d 178 (2d Cir.), cert. denied, 385 U.S. 817 (1966) (no private action under NASD rule requiring members to observe high standard of commercial honor and just and equitable principles of trade); Wells v. Blythe \& Co., [1972-1973 Transfer Binder] CCH Fed. SEc. L. ReP. II 93,759 (N.D. Cal. 1972) (no private action under NASD "suitability" rule, at least in absence of allegation of fraud); McMaster Hutchinson \& Co. v. Rothschild \& Co., [1972-1973 Transfer Binder] CCH FED. SEC. L. Rep. If 93,541 (N.D. 1l1. 1972) (no private action under NYSE "know-your-customer" mle); Aetna Cas. \& Sur. Co. v. Paine, Webber, Jackson \& Curtis, [1969-1970 Transfer Binder] CCH FED. SEc. L. REP. II 92,748 (N.D. Ill. 1970) (no private cause of action under NYSE Rule 405); Mercury Inv. Co. v. A.G. Edwards \& Sons, 295 F. Supp. 1160 (S.D. Tex. 1969) (no private action under NASD "suitability" rule); cf. Landy v. FDIC, 486 F.2d 139 (3d Cir. 1973), cert. denied, 94 S. Ct. 1979 (1974) (refusing to recognize an implied private right of action based on stock exchange rules where the plaintiff had not met his burden of proving that the implication was necessary). But see SEC v. First Sec. Co., 463 F.2d 981, 988 (7th Cir.), cert. denied, 409 U.S. 880 (1972) (upholding private action under NASD diligent supervision rule); Avern Trust v. Clarke, 415 F.2d 1238 (7th Cir. 1969), cert. denied, 397 U.S. 963 (1970) (upholding private cause of action under NASD "suitability" rule) (dictunn); Buttrey v. Merrill Lynch, 
firm under the securities acts rely on two other theories of liability: agency or "respondeat superior,"12 and the "controlling persons" liability provided by the federal statutes themselves. ${ }^{13}$ The distinction between these two theories is particularly important because of the differing defenses each affords. ${ }^{14}$ Yet recent cases indicate marked judicial confusion over which theory sets the appropriate and "correct" standard of liability.

This Note will analyze the "respondeat superior" and "controlling persons" theories of brokerage firm liability. In so doing, it will suggest that the controlling persons statutes have excluded the application of common law agency principles in suits under the federal securities laws. ${ }^{15}$ The Note will then discuss the statutory defenses of the controlling persons provisions and will conclude that, although neghigence is probably sufficient for brokerage firm liability under the the 1933 Act, recklessness should be required to impose liability under the 1934 Act.

\section{Agency and Controlling Persons liability: A Comparison}

This section of the Note will compare the two most frequently used theories under which brokerage firms have been held liable for their salesinen's violations of the federal securities laws. The first theory derives from the familiar common law doctrine which makes a principal liable for misrepresentations inade by an agent within the scope of the agent's actual or apparent authority. ${ }^{16}$ The second is

Pierce, Fenner \& Smith, Inc., 410 F.2d 135 (7th Cir.), cert. denied, 396 U.S. 838 (1969) (upholding private cause of action for violation of the "know-your-customer" requirement of NYSE Rule 405); Stevens v. Abbott, Proctor \& Pame, 288 F. Supp. 836, 846-47 (E.D. Va. 1968) (upholding private cause of action under both NASD and NYSE diligent supervision rules).

12. See cases cited in note 16 infra.

13. See cases cited in note 20 infra.

14. See text accompanying notes 28-44 infra.

15. For a contrary view, see Note, The Burden of Control: Derivative Liability Under Section 20(a) of the Securities Exchange Act, 48 N.Y.U.L. REv. 1019, 1033, 1041 (1973), which concludes that it would be "inconceivable" that section 20(a) was intended to limit existing respondeat superior hability. Id. at 1041. However, since the exclusivity principle would apply only to federal causes of action which did not exist under the general law, the continued viability of causes based on common law deceit or fraud would be in no way affected by the adoption of this principle. For a discussion of the elements of this common law tort, with specific reference to the securities law context, see 3 L. Loss, Securities Reguiation 1431-35 (2d ed. 1961). See text accompanying note 69 infra.

16. The RESTATEMENT (SECOND) OF AGENCY \& 257 (1958) provides:

A principal is subject to liability for loss caused to another by the other's reliance upon a tortious representation of a servant or other agent, if the representation is: 
provided by the express controlling persons sections of both federal securities acts. ${ }^{17}$

Section 20(a) of the 1934 Act imposes liability subject to a good faith defense on "[e]very person who, directly or indirectly, controls any person liable under" the antifraud provisions of the Act. ${ }^{18}$ Similarly, section 15 of the 1933 Act imposes liability, subject to a scienter requirement, on "[e]very person who, by or through stock ownership, agency, or otherwise . . . controls any person liable under" the antifraud provisions of the 1933 Act. $^{10}$ These controlling persons sections liave frequently been utilized to impose hability on a brokerage house for the fraudulent acts of securities salesmen. ${ }^{20} \mathrm{~A}$ number of courts
(a) authorized;
(b) apparently authorized; or
(c) within the power of the agent to make for the principal.

Cases applying this principle in suits under the federal secnrities laws to hold broker-dealers liable is principals include Fey v. Walston \& Co., 493 F.2d 1036 (7th Cir. 1974); Lewis v. Walston \& Co., 487 F.2d 617 (5th Cir. 1973); SEC v. First Sec. Co., 463 F.2d 981 (7th Cir.), cert. denied, 409 U.S. 880 (1972); Johns Hopkins Univ. v. Hutton, 422 F.2d 1124 (4th Cir. 1970), aff'g in part and rev'g in part $297 \mathrm{~F}$. Supp. 1165 (D. Md. 1968); Armstrong, Jones \& Co. v. SEC, 421 F.2d 359 (6th Cir. 1970); SEC v. Charles A. Morris \& Associates, Inc., [1972-1973 Transfer Binder] CCH FED. SEC. L. REP. T 93,756 (W.D. Tenn. 1973).

17. Securities Act of $1933 \S 15,15$ U.S.C. $\$ 770$ (1970); Securities Exchange Act of $1934 \S 20(a), 15$ U.S.C. $\$ 78 t(a)(1970)$.

18. Section 20(a) provides:

Every person who, directly or indirectly, controls any person liable under any provision of this chapter or of any rule or regulation thereunder shall also be liable jointly and severally with and to the same extent as such controlled person to any person to whom such controlled person is liable, unless the controlling person acted in good faith and did not directly or indirectly induce the act or acts constituting the violation or cause of action. 15 U.S.C. $\$$ $78 \mathrm{t}$ (a) (1970).

19. Section 15 provides:

Every person who, by or through stock ownership, agency, or otherwise, or who, pursuant to or in connection with an agreement or understanding with one or more persons by or through stock ownership, agency, or otherwise, controls any person liable under sections $77 \mathrm{k}$ or $77 i$ of this title, shall be liable jointly and severally with and to the same extent as sucli controlled person to any person to whoin such controlled person is liable, unless the controlling person had no knowledge of or reasonable ground to believe in the existence of the facts by reason of which the liability of the controlled person is alleged to exist. 15 U.S..C $\$ 770$ (1970).

No one has adequately accounted for the differences in wording between the two sections. Presumably the reference to direct and indirect control in section 20(a) is merely a shorthand way of saying "by or through stock ownership, agency, or otherwise" as stated in section 15. It is more difficult to explain the difference in the defenses provided, although Loss has suggested that the good faith defense of section 20(a) is an easier defense to make. See 3 L. Loss, Securmites Regulation 1747 (2d ed. 1961).

20. See, e.g., SEC v. First Sec. Co., 463 F.2d 981 (7th Cir.), cert. denied, 409 U.S. 880 (1972); Gordon v. Burr, 366 F. Supp. 156 (S.D.N.Y. 1973); SEC v. Lum's, Inc., 365 F. Supp. 1046 (S.D.N.Y. 1973); Anderson v. Francis I. duPont \& Co., 291 
have not been content to rest their decisions upon one analysis or the ather, and have instead employed bath theories of liability. ${ }^{21}$

The choice of theory-agency or controlling persons liabilityis important because, under agency law, the brokerage firm is much more likely to be found liable. The broker-dealer is liable for all losses caused by the misrepresentations of an agent. ${ }^{22}$ Therefore, once the fraud of the wrongdoing salesman is established, liability will almost invariably be imposed. SEC v. First Securities $C_{0 .}{ }^{23}$ a receivership proceeding, illustrates the judicial propensity to construe the scope of agency broadly. There the president of the defendant brokerage firm induced fifteen of the firm's regular customers to invest in a fraudulent escrow account. While no one at First Securities except the president's secretary even knew of the escrow's existence, ${ }^{24}$ the court cited numerous circumstances indicating that the president had in fact acted with "apparent authority": (1) the victims had all been regular brokerage clients of the company; (2) the investunent recoinmendation was made to fourteen of the fifteen claimants in the president's office; (3) the claimants sold legitimate securities through First Securities for purposes of obtaining the necessary cash to invest in the escrow; (4) substantially all correspondence with the victims was written on letterhead stationery of First Securities; (5) much of the correspondence was typed by the president's secretary (although some correspondence was handwritten); and (6) while "interest payments" on the escrow were made by the president's personal check, the interest payments were sent in a First Securities envelope. ${ }^{25}$ Denying that any verbal representations by the president that he was acting on behalf of his principal were essential to the firm's liability, the Seventh Circuit held that the above circunstances sufficiently showed the president's apparent authority. ${ }^{26}$ While the court did not specify which factors it deemed most important, agency liability probably will be imposed at least whenever the plaintiffs have been regular customers of the defendant brokerage firm, have sold stocks out of their accounts

F. Supp. 705 (D. Minn. 1968); Hecht v. Harris, Upham \& Co., 283 F. Supp. 417 (N.D. Cal. 1968), modified on other grounds, 430 F.2d 1202 (9th Cir. 1970); Hawkins v. Merrill Lynch, Pierce, Fenner \& Beane, 85 F. Supp. 104 (W.D. Ark. 1949).

21. See notes $48-51$ infra and accompanying text.

22. See Restatement (Second) of Agency $\$ 257$ (1958), quoted in note $16 \mathrm{su-}$ pra.

23. 463 F.2d 981 (7th Cir.), cert. denied, 409 U.S. 880 (1972).

24. $I d$. at 985 .

25. Id. at $983-84$.

26. Id. at 986 . 
to invest in the fraudulent scheme, and have been solicited by the salesman in the brokerage office. ${ }^{27}$

The only defense readily available to the brokerage house is that the wrongdoer acted neither as an express nor as an apparent agent of the firm. The tendency of courts is to construe this defense narrowly, and its applicability in a given case must be clearly demonstrated. For example, in Sennott v. Rodman \& Renshaw ${ }^{28}$ a commodities trader brought suit against the brokerage house of Rodman \& Renshaw alleging that the son of a partner in the firm had sold him nonexistent stock through the defendant's brokerage offices. While the son was not employed by the firm, ${ }^{20}$ he customarily approached the plaintiff on the Chicago Board of Trade floor, advised him of favorable investments, and called in the plaintiff's order on the Rodman phone. ${ }^{30}$ These facts appeared to make the salesman an agent of the firm, but the defendant pointed out that the purchase in question was made instead by secret agreement between plaintiff and the salesman ${ }^{31}$ and that the plaintiff had angrily refused to cooperate in a firm investigation into the activities of the son, even when shown that his checks given in payment for the nonexistent stock had been endorsed by the son's wife and deposited in her personal account. ${ }^{32}$ The Seventh Circuit, therefore, concluded that the plaintiff's purchase of the stock was made in rehance merely on the personal integrity of the son and not on the son's apparent authority as an agent of Rodman. ${ }^{33}$ Similarly, the defendant brokerage firm may escape liability under an apparent agency theory if the wrongdoing salesman's act was so obviously illegal that any reliance by the plaintiff on the salesman's authority would be clearly unreasonable. ${ }^{34}$

27. See Lewis v. Walston \& Co., 487 F.2d 617 (5th Cir. 1973); cf. Fey v. Walston \& Co., 493 F.2d 1036 (7th Cir. 1974) (brokerage firm may be held liable for salesman's churning of account where brokerage firm shared the commissions earned).

28. 474 F.2d 32 (7th Cir.), cert. denied, 414 U.S. 926 (1973).

29. Id. at 33.

30. Id. at 34 .

31. Id. at 39.

32. Id. at 36 .

33. Id. at 39 .

34. See Kamen \& Co. v. Paul H. Aschkar \& Co., 382 F.2d 689 (9th Cir. 1967), cert. dismissed, 393 U.S. 801 (1968), where two employees of the defendant Kamen set up a fraudulent scheme to capture the "listed business" of non-exchange member broker-dealers for Kamen. Without the knowledge of the Kamen firm's partners, see id. at $691-92$, the scheme worked by promising over-the-counter broker-dealers that Kamen would channel certain business in non-listed securities back to them. Broker $A$ was called and told to purchase a certain number of valueless shares of a certain company from Broker $B$ at a specific price and to sell the shares to Broker $C$ at a slightly higher price. Unknown to Broker $A$, Broker $C$ was then told to purchase the shares froin 
Under the controlling persons sections of the securities acts, on the other hand, the defendant broker-dealer is given two defenses. First, just as a brokerage firm can under the common law principles of agency contend the firm did not expressly or apparently authorize the alleged agent's acts, the brokerage firm can, under the controlling perons provisions, contend it did not "control" the wrongdoing salesman. ${ }^{35}$ However, the importance of this first defense should not be overstated. It is, in fact, less helpful to a defendant brokerage house than is the "lack of an agency" defense. The reason is that the defimition of agency is much narrower than that of a control relationship. ${ }^{36}$ The former is defined as a relation created by a manifestation of willingness and consent by both the agent and the principal that the agent is to act for the principal. ${ }^{37}$ The latter, however, can exist without a principal-agent relationship. ${ }^{38}$ The courts have consistently held that the "[controlling persons] statute[s] [are] remedial and [are] to be construed liberally. . . . Only some indirect means of discipline or influence short of actual direction [is necessary] to hold a 'controlling person' liable."39 Moreover, one may be a controlling person without

Broker $A$ and to sell them to Broker $D$ at a still higher price, and so on. Id. at 692 . Aschkar, the plaintiff, was one of those induced to buy the stock, but just at that time the scheme collapsed, and the plaintiff was left without a purchaser. Id. at 692-93. The Ninth Circuit held that, while the salesmen were unquestionably agents of the defendant brokerage firm, they had neither actual nor "ostensible" (apparent) authority to carry on their fraudulent activities. The court explained that "ostensible" authority arises as a result of conduct of the principal which causes the third party reasonably to believe that the agent possesses the authority to act on the principal's behalf. Id. at 695 . Here, however, any reliance on the agent's authority was clearly unreasonable since Aschkar knew that guaranteed profit sales violated exchange rules. Id. at 696. Therefore, the Kamen firm could not be held liable under agency principles. Id.

A similar defense was interposed in Hawkins v. Merrill Lynch, Pierce, Fenner \& Beane, 85 F. Supp. 104 (W.D. Ark. 1949), but the defendants were held liable as controlling persons despite the fact that they were not the wrongdoer's principal. Id. at 122-24.

35. This defense was also successfully raised by the Rodman \& Renshaw firm in Sennott. The court explained that the activity in question was so remote and unrelated to Rodman that the brokerage firm could not possibly be deemed to be in control of the wrongdoer. 474 F.2d at $39-40$.

36. It should be noted that section 15 of the 1933 Act specifically enumerates agency as only one of several suggested means of control. See note 19 supra.

37. Ruder 605. See Restatement (SeCOND) OF AgEnCY $\$ 15$ (1958).

38. Harriman v. E.I. DuPont de Nemours \& Co., CCH FED. SEC. L. ReP. It 94,399, at 95,365 (D. Del. Jan 16, 1974); Moscarelli v. Stamm, 288 F. Supp. 453, 460 n.5 (E.D.N.Y. 1968); Hawkins v. Merrill Lynch, Pierce, Fenner \& Beane, 85 F. Supp. 104, 123 (W.D. Ark. 1949).

39. Myzel v. Fields, 386 F.2d 718, 738 (8th Cir. 1967), cert. denied, 390 U.S. 951 (1968); accord, Harriman v. E.I. DuPont De Nemours \& Co., CCH FED. SEC. L. REP. Tा 94,399, at 95,366 (D. Del. Jan. 16, 1974); Jezarian v. Csapo, [1972-1973 Transfer 
having in fact exercised control. ${ }^{40}$

The second defense-and the one which nakes liability under the controlling persons sections more difficult to establish than under transplanted agency principles-is provided by the express statutory language. Section 20(a) imposes liability "unless the controlling person acted in good faith and did not directly or indirectly induce the act or acts constituting the violation or cause of action."41 Section 15 results in liability "unless the controlling person had no knowledge of or reasonable ground to believe in the existence of the facts by reason of which the hability of the controlled person is alleged to exist." 42 These defenses, although by no means an absolute bar to recovery, ${ }^{43}$ are at least formidable enough to encourage plaintiffs to place foremost rehance on agency principles in a cause of action for a federal securities violation. Only in the absence of an einployment relationship between salesman and broker-dealer, where an agency relationship might be difficult to establish, would the investor by choice rely upon the controlling persons sections. ${ }^{44}$

\section{Are the Controlling Persons Sections Exclusive?}

One of the most unsettled questions in securities law is whether or not the controlling persons sections are exclusive in a federal cause of action, thus preventing imposition of the strict liability flowing from

Binder] CCH FED. SEC. L. REP. Tा 93,795, at 93,439 (S.D.N.Y. 1973); Anderson v. Francis I. duPont \& Co., 291 F. Supp. 705, 710 (D. Minn. 1968).

40. Harriman v. E.I. DuPont De Nemours \& Co., CCH Fed. SEc. L. Rep. II 94,399 , at 95,366 (D. Del. Jan. 16, 1974).

41. 15 U.S.C. $\S 78 \mathrm{t}(\mathrm{a})(1970)$.

42. 15 U.S.C. $\$ 770(1970)$.

43. See, e.g., Lorenz v. Watson, 258 F. Supp. 724 (E.D. Pa. 1966); Hawkins v. Merrill Lynch, Pierce, Fenner \& Beane, 85 F. Supp. 104 (W.D. Ark. 1949). See generally Comment, Brokerage Firm's Liability for Salesman's Fraudulent Practices, 36 ForDHAM L. Rev. 95, 98-101 (1967).

44. For cases where an investor attempted to hold a brokerage firm liable for the acts of a salesman not actually employed by the brokerage firm, see Sennott v. Rodman \& Renshaw, 474 F.2d 32 (7th Cir.), cert. denied, 414 U.S. 926 (1973); Anderson v. Francis I. duPont \& Co., 291 F. Supp. 705 (D. Minn. 1968); Hawkins v. Merrill Lynch, Pierce, Fenner \& Beane, 85 F. Supp. 104 (W.D. Ark. 1949).

For another situation where it would be difficult to rely on an agency theory of liability, see Hughes v. Dempsey-Tegeler \& Co., [1973 Transfer Binder] CCH Fed. SEc. L. REP. I 94,133, at 94,524-54 (C.D. Cal. Sept. 4, 1973) (suit by investor against stock exchange for fraudulent acts committed by brokerage louse and agents thereof). While no agency theory of liability was proposed in Hughes, the court did lold that the exchange was a "controlling person." Id. at 94,551. However, the exchange was lield to liave satisfied the good faith defense and thus was not lield liable. Id. at 94,552. See also DeMarco v. Edens, 390 F.2d 836, 844 (2d Cir. 1968) (no agency relation exists between issuer and underwriter). 
general agency principles. ${ }^{45}$ The District Court for the Southern District of New York has twice upheld exclusivity. ${ }^{46}$ At least five other courts have applied agency principles instead of the relevant controlling persons section, thus stripping the firm of its statutory defenses. ${ }^{47}$ Some courts have considered both theories, although inost such cases have held the defendant brokerage house inculpable under both. ${ }^{48}$ No case appears to have arisen where the "good faith" defense was satisfied but the strict hability of the agency relationship was nevertheless imposed. Thus, the courts' consideration of agency principles, which provide far less readily available defenses than the controlling persons statutes, has not yet been detrimental to defendants. However, in Hawkins v. Merrill Lynch, Pierce, Fenner \& Beane, ${ }^{49}$ another case considering both agency and controlling persons hability, the reverse happened. The wrongdoing salesman, although not an agent of the defendant Merrill Lynch, was found to be "controlled by" the brokerage firm. ${ }^{50}$ Since the court held Merrill Lynch had not satisfied the "good faith" defense, liability was imposed under section 20(a). ${ }^{51}$

The legislative history of sections 15 and 20(a) does not definitively answer the question of whether, in an action brought under the securities acts, these sections preclude imposing strict liability on a brokerage firm merely on a showing that it is the principal. There is soine indication, based on differences between the House and Senate drafts of the 1933 Act, that section 15 was not initially intended to govern the brokerage einployee situation. The original Senate version merely contained several "dummy" director provisions designed to prevent directors from evading the liabilities incident to signing a registration statement by having "dummies" sign in their place. ${ }^{52}$ The

45. For a general discussion of the construction of statutes in derogation of the common law, see 2A J. SUtherdand, Statutes and Statutory Construction $\$ 50.05$ (Sand 4th ed. 1973).

46. See Gordon v. Burr, 366 F. Supp. 156 (S.D.N.Y. 1973); SEC v. Lum's, Inc., 365 F. Supp. 1046 (S.D.N.Y. 1973).

47. See Fey v. Walston \& Co., 493 F.2d 1036 (7th Cir. 1974); Lewis v. Walston \& Co., 487 F.2d 617 (5th Cir. 1973); Johns Hopkins Univ. v. Hutton, 422 F.2d 1124 (4th Cir. 1970), aff'g in part and rev'g in part 297 F. Supp. 1165 (D. Md. 1968); Armstrong, Jones \& Co. v. SEC, 421 F.2d 359 (6th Cir. 1970); SEC v. Charles A. Morris \& Associates, Inc., [1972-1973 Transfer Binder] CCH Fed. SEC. L. Rep. If 93,756 (W.D. Tenn. 1973).

48. See, e.g., Sennott v. Rodman \& Renshaw, 474 F.2d 32 (7th Cir.), cert. denied, 414 U.S. 926 (1973); Kamen \& Co. v. Paul H. Aschkar \& Co., 382 F.2d 689 (9th Cir. 1967), cert. dismissed, 393 U.S. 801 (1968).

49. 85 F. Supp. 104 (W.D. Ark. 1949).

50. Id. at 123 .

51. Id.

52. S. Rep. No. 47, 73d Cong., 1st Sess. 5-6 (1933); see S. 875, 73d Cong., 1st Sess. $\S \S 2(\mathrm{k}), 4,9,13$ (1933), reprinted in 77 CoNG. REc. $2979-82$ (1933). 
House version, while imposing liability on directors for false registration statements, did not contain either a "dummy" provision or a controlling persons provision. ${ }^{53}$ In conference, the Senate provision became the present section 15 of the 1933 Act. $^{54}$ Thus, arguably section 15 was merely the result of congressional concern with the special probleins presented by the use of dummy directors and was not designed to cover the salesinan-brokerage firm relationship.

This justification for a standard of strict liability flowing from the agency relationship is insufficient for two reasons. First, it fails to explain why section 15 is written in much more general terms than the original Senate provision. A House report describing the amendment to section 15 , which added the scienter test for controlling persons liability, is written in equally broad terms. ${ }^{55}$ The report contains no hint that section 15 , clear on its face, is limited in its application. Second, even assuming that section 15 was not meant to apply to employment relationships, there is no similar legislative history mandating such a limitation on section 20(a) of the 1934 Act. $^{53}$ On the contrary, the legislative history indicates that Congress intended a very broad definition of control:

In this section . . . when reference is made to "control," the term is intended to include actual control as well as what has been called legally enforceable control . . . . It would be difficult if not impossible to enumerate or to anticipate the many ways in which actual control may be exerted. A few examples of the methods used are stock ownership, lease, contract, and agency . . . .57

The most lucid federal securities act decision applying agency principles rather than the appropriate controlling persons section (thereby avoiding the firm's possible statutory defenses) is Johns Hopkins University v. Hutton. ${ }^{58}$ Johns Hopkins brought suit against W.E.

53. H.R. ReP. No. 152, 73d Cong., 1st Sess. 27 (1933).

54. See id.

55. See H.R. Rep. No. 1838, 73d Cong., 2d Sess. 42 (1934). The amendment to section 15 added the words "unless the controlling person had no knowledge of or reasonable ground to believe in the existence of the facts by reason of which the liability of the controlled person is alleged to exist." Id. at 49.

56. Because of the sweeping scope of Rule 10b-5 most suits against brokerage firms come under the 1934 Act. See note 83 infra and accompanying text.

57. H.R. REP. No. 1383, 73d Cong., 2d Sess. 26 (1934) (emphasis added).

58. 297 F. Supp. 1165 (D. Md. 1968), aff'd in part and rev'd in part, 422 F.2d 124 (4th Cir. 1970). The holding in Johns Hopkins has been followed by the Seventh Circuit in Fey v. Walston \& Co., Inc., 493 F.2d 1036 (7th Cir. 1974). Interestingly, the other three courts which have applied agency principles instead of the controlling persons sections in suits against brokerage houses for their salesmen's misconduct, see cases cited in note 47 supra, have not even considered the possible applicability of the 
Hutton \& Co., a brokerage firm, to rescind the University's purchase of an oil and gas production payment on the ground that a Hutton employee had falsely predicted future net revenues for the oil wells. The district court held that the controlling persons liability of section 15 merely supplements common law principles of agency and respondeat superior. ${ }^{59}$

The legislative history and case law, to the extent there is any, would appear to buttress a contruction of section 15 to exclude application of the latter to an employment relationship. A contrary conclusion would in effect give blessing to a hear-no-evil, see-no-evil approach by partners of a brokerage house which is hardly in keeping with the remedial purposes of the ' 33 Act . . . . ${ }^{60}$

If Hutton escaped liability because its partners had no knowledge of or reasonable grounds to believe in the employee's misrepresentations, the court speculated, then the partners in a brokerage house could insulate themselves from liability under the federal securities acts by simply ignoring employee sales practices. ${ }^{61}$ Although the Fourth Circuit agreed with the reasoning of the district court, ${ }^{62}$ the fear that brokerage louses would frequently escape section 15 liability when they would have been held culpable under a strict liability standard is probably not justified. The words "reasonable grounds to believe" should be construed to impose liability where the einployer should have known of the salesman's fradulent conduct or the likelihood thereof. $^{63}$ Furthermore, under the 1934 Act, the intentional disregard

controlling persons provisions.

Besides this judicial support for the contention that the controlling persons provisions do not supplant agency liability, two commentators, Professors Bromberg and Ruder, also agree with the non-exclusivity view. See 1 BROMBERG $\$ 6.1(100)$, at 107 n.11; Ruder 608. Not surprisingly, the SEC has taken a similar position. See Briefs for SEC as Amicus Curiae, Kamen \& Co. v. Paul H. Aschkar \& Co., 390 U.S. 942 (1968), cited in Ruder 606-07. The Supreme Court, however, never decided the issue in Kamen, as certiorari was later dismissed by agreement between the parties. 393 U.S. 801 (1968). The SEC unsuccessfully advanced the same argument in SEC v. Lum's, Inc., 365 F. Supp. 1046 (S.D.N.Y. 1973). There is some indication that at least two members of the Supreme Court would find a brokerage firm liable on agency principles. See Sennott v. Rodman \& Renshaw, 414 U.S. 926 (Douglas \& Blackmun, J.J., dissenting), denying cert. to 474 F.2d 32 (7th Cir. 1973).

59. 297 F. Supp. at 1212.

60. Id.

61. See id at 1212-13.

62. 422 F.2d 1124, 1128, 1131 (4th Cir. 1970).

63. See DeMarco v. Edens, 390 F.2d 836 (2d Cir. 1968). This was a suit against the issuing corporation for the fraudulent conduct of its underwriter. The court, although exculpating the defendant from liability under section 15 , inquired not only into the defendant's actual knowledge of the fraud but also into the issuer's exercise of reasonable care in investigating the underwriter. Id. at 842-43. 
of employee sales practices would certainly be evidence of blatant bad faith.

An additional argument against the exclusivity of the controlling persons sections can be based on the language of section 28(a) of the 1934 Act: "The rights and remedies provided by this chapter shall be in addition to any and all other rights and remedies that may exist at law or in equity . . . ." This argument appears to be the basis for the Seventh Circuit's recent holding in Fey v. Walston \& Co. ${ }^{05}$ that section 20(a) does not exclude federal securities liability predicated upon agency principles. While the court did not expressly cite section 28(a), the Seventh Circuit stated that "the mere existence of remedial provisions in the Securities Acts does not foreclose the appication of similar common law remedies."0s An analogy can also be drawn to a line of cases holding that remedies under the federal securities acts are cumulative, not mutually exclusive, and that therefore an implied cause of action exists under rule $10 \mathrm{~b}-5$ despite the availability of another remedy under an express civil liability section. ${ }^{67}$

However, such an importation of agency principles into the federal securities laws will often render the controlling persons sections superfluous in a context to which they clearly apply: the control re-

64. 15 U.S.C. $\$ 78 \mathrm{bb}$ (a) (1970) (emphasis added). Parallel language is found in section 16 of the 1933 Act, 15 U.S.C. \$ 77p (1970).

65. 493 F.2d 1036 (7th Cir. 1974). In Fey the plaintiff, a widow, alleged that her account had been churned and brought suit under rule 10b-5. The trial court rendered judgment for the plaintiff in the sum of $\$ 18,227.04$. On appeal the defendant brokerage firm complained that the court failed adequately to instruct the jury as to the statutory defense provided by section 20(a). The Seventh Circuit held that even if the charge were erroneous, the defendant could not complain since the firm could be held liable for its employee's 10b-5 violation under respondeat superior and therefore had obtained a more favorable instrnction than it was entitled to. Id. at 1052. The case, however, was reversed and remanded because other charges were found to be erroueous.

66. Id. at 1052 n.18. The court went on to state that the converse was also true: a statutory remedy may be invoked even though the proof is insufficient to sustain a corresponding common law remedy. Id. As further authority for its holding the court cited Affiliated Ute Citizens v. United States, 406 U.S. 128 (1972), in which a defendant bank was held "coextensively" liable for the $10 \mathrm{~b}-5$ violation of its officer-employees. The Court, however, did not give any reasons for its holding. Whatever theory the Court had in mind, the case is clearly distinguishable from suits against brokerage houses for their salesinen's acts. A corporation is always liable for the fraudulent acts of its officers-as distinguished from lower level employees-since the acts of the offieers are imputed to the corporation. See SEC v. Lum's, Inc., 365 F. Supp. 1046, 1061 (S.D.N.Y. 1973).

67. See, e.g., Jordan Bldg. Corp. v. Doyle, O'Connor \& Co., 401 F.2d 47 (7th Cir. 1968); Orn v. Eastman Dillon, [1973 Transfer Binder] CCH Fed. Sec. L. Rep. IT 94,189 (C.D. Cal. Oct. 2, 1973); Stewart v. Bennett [1973 Transfer Binder] CCH FED. SEC. L. REP. ๆ 94,140 (D. Mass. 1973); Rotstein v. Reynolds \& Co., 359 F. Supp. 109 (N.D. I11. 1973). 
lationship of a broker-dealer and its employees. ${ }^{68}$ While section 28(a) does provide that the rights and remedies under the 1934 Act are in addition to those granted by common law, this section was merely meant to preserve actions for common law fraud or deceit. ${ }^{69}$ A plaimtiff should not, in the interest of fairness, be permitted to sue under one of the broad federal antifraud provisions and, at the same time, hold the defendant broker-dealer absolutely liable in derogation of the defenses provided as pant of the same statutory scheme. When the cause of action is based upon the federal securities laws, the liability of the defendant brokerage firm should be determined under the appropriate controlling persons section. On the other hand, if a plaintiff further alleges common law fraud or deceit by the salesman, then the liability of the broker-dealer for that additional count should be determined under common law agency principles. ${ }^{70}$ Of course, under the appropriate facts a defendant can be held liable under both theories, ${ }^{71}$ but the two causes of action allow the broker different defenses, and the two standards of liability should not be confused. This argument was suggested in Moscarelli v. Stamm ${ }^{72}$ where the court, by way of dictum, stated that "[w] hich provision is applicable may depend upon whether the cause of action is predicated upon a statutory tort under the federal securities laws or upon a common law tort."73

The foregoing section las considered and rejected the various arguments for coexistence, within a federal securities act cause of action, of agency and controlling persons liability. Finally, it must be emphasized that the strongest argument for the exclusivity of the standard of liability of the controlling persons sections arises from the statutory language itself. This contention has received judicial recognition only recently in SEC $v$. Lum's, Inc., ${ }^{74}$ an enforcement proceeding under rule $10 \mathrm{~b}-5$ against Lehman Brothers and a registered representative for "tipping" a major institutional client regarding an expected earnings decline in Lum's stock. ${ }^{75}$ In holding that liability

68. See Comment, supra note 43 , at 97 . For those limited situations in which the controlling persons sections would not be superfluous, see cases cited in note 44 supra.

69. See 1 L. Loss, Securities Rfgulation 156 (2d ed. 1961).

70. See Moscarelli v. Stamm, 288 F. Supp. 453, 460-61 (E.D.N.Y. 1968).

71. For an example where this was done, see SEC v. First Sec. Co., 463 F.2d 981 (7th Cir.), cert. denied, 409 U.S. 880 (1972).

72. 288 F. Supp. 453 (E.D.N.Y. 1968).

73. $7 d$. at 460 n.6.

74. 365 F. Supp. 1046 (S.D.N.Y. 1973). The holding in Lum's has been followed in Gordon v. Burr, 366 F. Supp. 156 (S.D.N.Y. 1973).

75. Accordimg to the complaint, a director and chief operating officer of Lum's (a franchisor of fast-food restaurants and owner of Caesar's Palace in Las Vegas) received a non-public, pessimistic earnings projection which he relayed to a registered represent- 
could not be imposed on Lehman Brothers without regard to any possible lack of "fault," the court carefully exainined the language of the controlling persons sections. On their face, the court noted, the sections would seein to cover the employer-employee situation, ${ }^{70}$ since section 20 (a) apphes to "[e]very person, who, directly or indirectly, controls any person liable under any provision of this chapter or of any rule or regulation thereunder,"77 and section 15 applies to "[e]very person who, by or through stock ownership, agency or otherwise . . . controls any person liable under sections $77 \mathrm{k}$ or $77 l \ldots . .978$ Since section 15 specifically defines "control" in terms of agency, ${ }^{79}$ and since a House report indicates a similar construction of section 20 (a),${ }^{80}$ the controlling persons provisions squarely exclude the application of strict liability based on common law agency principles im federal securities acts cases. ${ }^{81}$

ative at Lehman Brothers. The representative then conveyed the information to Investors Diversified Service, Inc., which quickly thereafter dumped its 83,000 shares of Lum's. See 365 F. Supp. at 1050.

76. Id. at 1063.

77. Id. (emphasis added by the court).

78. Id. (emphasis added by the court).

79. See note 19 supra.

80. See note 57 supra and accompanying text.

81. The court in Lum's, seeking further justification for exclusivity, interpreted the landmark case of Lanza v. Drexel \& Co., 479 F.2d 1277 (2d Cir. 1973) as implying that section 20(a) sets the correct standard of liability for broker-dealers. In Lanza a partner in the brokerage firm of Drexel \& Co. was a director of BarChris Construction Co. In an acquisition negotiation certain other directors and officers of BarChris made fraudulent misrepresentations to the holders of Victor Billiard stock. Since the Drexel partner was unaware of the misrepresentations, he was not held liable under rule $10 \mathrm{~b}-5$. Id. at 1289 . Consequently, the court did not actually reach the question of whether Drexel had liability either under respondeat superior (as the plaintiff alleged, id. at 1280) or under the controlling persons sections (as Mr. Justice Hays argued in his dissenting opinion, id. at 1319-20).

Nevertheless, the court in Lum's read Lanza as authority for imposing liability on Lehman Brothers under section 20(a) for the acts of the employee-salesman. $365 \mathrm{~F}$. Supp. at 1063. Despite this construction, the court declined to apply Lanza or the controlling persons sections to Ium's itself. Rather, since the court could not conceive of a corporation acting in any other way than through its officers and directors, Ium's was held liable under agency principles for the act of its "tipping" director. Id. at 1061. The court admitted, however, that the result would be the same under section 20(a). Id.

Hecht v. Harris, Upham \& Co., 283 F. Supp. 417 (N.D. Cal. 1968), modified on other grounds, 430 F.2d 689 (9th Cir. 1970), another case cited in Lum's as supporting exclusivity, is a more questionable authority, since the exact holding in Hecht is unclear. While the court noted that Harris Upham had failed to comply with the requirements for internal supervision as provided in section 20(a), the court at another point stated, "A stock brokerage firm can act only through its various partners and employees and agents, and [their acts] . . . are the acts of the firm." 283 F. Supp. at 443. Thus, the court may actually have found both agency primciples and section 20(a) ap- 


\section{The Good Faith Defense}

Once it is accepted that the controlling persons sections are the appropriate standard for determining the liability of a brokerage firm for the federal securities violations of its salesmen, the fimal issue for determination is the breadth of the broker-dealer's statutory defenses.

It has been suggested that

the 1934 Act gives the controlling person a seemingly readier defense than the 1933 Act. Under section 20(a) of the 1934 Act the controlling person need prove only that he "acted in good faith and did not directly or indirectly induce the act or acts constituting the violation or cause of action," whereas under section 15 of the 1933 Act the controlling person must prove that he "had no knowledge of or reasonable grounds to beheve in the existence of the facts by reason of which the hability of the controlled person is alleged to exist." 82

However, because of the broad scope of rule $10 \mathrm{~b}-5$, most suits by investors against broker-dealers and their employees fall under the 1934 Act $^{83}$ despite the greater difficulty in overcoming defenses, and therefore few cases have construed the controlling persons section of the 1933 Act. The best construction, however, appears to be that, in order to escape liability under section 15 , controlling persons inust exercise the "reasonable care" of a "person of ordinary prudence" to ascertain violations of the federal securities acts. ${ }^{84}$ This construction implies some burden of investigation into the conduct of the controlled person, and, if reasonable care is given its common law meaning, then a brokerage firm which is inerely negligent in its supervision of salesmen may nonetheless be held liable. ${ }^{85}$

The nature of the "good faith" defense provided by the 1934 Act has been far more frequently litigated, and the courts have achieved varying results. The leading case construing section 20(a) is Lorenz

plicable. This would be consistent with the Ninth Circuit's earlier holding in Kamen \& Co. v. Paul H. Aschkar \& Co., 382 F.2d 689 (9th Cir. 1967), cert. dismissed, 393 U.S. 801 (1968). The court in Lum's read Kamen as holding that the "controlling persons" sections provide the exclusive basis of broker-dealer liability, 365 F. Supp. at 1062-63, but this appears to be an erroneous reading of the case, see note 34 supra.

82. 3 L. Loss, SECuRITIES REGULATION 1747 (2d ed. 1961) (citation omitted).

83. See 1 BROMBERG $\S 2.5(6)$, reporting that " $10 b-5$ is generating allnost as much litigation as all the other general antifraud provisions together, and several times as much as the express liabilities."

84. See DeMarco v. Edens, 390 F.2d 836, 842-43 (2d Cir. 1968).

85. See Folk, Civil Liabilities Under the Federal Securities Acts: The BarChris Case, Part II-The Broader Implications, 55 VA. L. Rev. 199, 216-24 (1969) (suggesting that controlling persons under section 15 must exercise "a reasonable degree of attention to the conduct of those whose actions presumably benefit them," id. at 224, a burden somewhat akin to that imposed under section 12(2) of the $1933 \mathrm{Act}$ ). 
v. Watson, ${ }^{86}$ an action brought by an elderly couple who alleged churning of their account at Bioren \& $\mathrm{Co}^{87}$ In denying summary judgment for the defendant brokerage house, the court held that in order to satisfy the requirement of good faith, the defendants had to show that some precautionary measures were taken and enforced to prevent the injury suffered. ${ }^{88}$ Thus, the good faith defense has come to resemble the requirement of proper supervision imposed by NYSE Rule 405 ,"1 section 27 of the NASD Rules of Fair Practice, ${ }^{90}$ and by the 1934 Act itself. ${ }^{.1}$ As stated in SEC v. Lum's, Inc.:

Whether this alleged failure to supervise vitiates the "good faith" defense provided under $\S 20(a), \ldots$ or whether it constitutes sufficiently negligent conduct to render Lehman directly liable as a participant according to the SEC, doubtless are two different ways of phrasing the same question. ${ }^{.2}$

Recent decisions employing an adequate supervision standard have imposed a high burden of supervision on brokerage firms and have thus construed the good faith defense narrowly. In SEC v. First Securities $C o .{ }^{93}$ the president of the defendant brokerage firm persuaded fifteen customers to invest in a nonexistent escrow fund; ${ }^{94}$ the scheme was facilitated by a rule of the brokerage house that mail addressed to the president's attention was not to be opened by anyone else. ${ }^{\text {.5 }}$ Holding that this rule constituted a breach of the duty of adequate supervision, the court thereby demied the employer's good faith defense and rendered the brokerage firm hable as a controlling person

86. 258 F. Supp. 724 (E.D. Pa. 1966).

87. Churning is the overtrading of an account in order to generate commissions. See 3 L. Loss, Securtites Regulation 1479-80 (2d ed. 1961).

88. See 258 F. Supp. at 732; accord, SEC v. First Sec. Co., 463 F.2d 981, 987 (7th Cir.), cert. denied, 409 U.S. 880 (1972); Gordon v. Burr, 366 F. Supp. 156 (S.D.N.Y. 1973); Hughes v. Dempsey-Tegeler \& Co., [1973 Transfer Binder] CCH FED. Sec. L. REP. II 94,133, at 94,550 (C.D. Cal. Sept. 4, 1973); Hecht v. Harris, Upham \& Co., 283 F. Supp. 417, 438 (N.D. Cal. 1968), modified on other grounds, 430 F.2d 1202 (9th Cir. 1970).

89. See note 8 supra.

90. See note 9 supra.

91. See section 15(b)(5)(E) of the 1934 Act, 15 U.S.C. $\S 78 o(b)(5)(E)$ (1970); mle 15b10-4, 17 C.F.R. \$ $240.15 b 10$ (1973).

92. 365 F. Supp. 1046 (S.D.N.Y. 1973); cf. Gordon v. Burr, 366 F. Supp. 156 (S.D.N.Y. 1973) (defendant brokerage firm failed to call any witnesses at trial to testify with regard to a system of adequate supervision and was therefore found not to have satisfied the good faith requirement).

93. 463 F.2d 981 (7th Cir.), cert. denied, 409 U.S. 880 (1972). See text accompanying notes $23-27$ supra.

94. $I d$. at $983-84$.

95. Id. at $985,987$. 
under section 20(a). ${ }^{96}$ The strictness of the requisite supervision is readily apparent if even the daily activities of the firm president must come within the scrutiny of a watchdog system of checks and balances. In Hecht v. Harris, Upham \& Co., ${ }^{97}$ a brokerage firm was held liable for its salesman's churning of an account where, in contravention of the firm's own rules requiring special treatment for female customers' commodities accounts, Ms. Hecht's account was opened and her portfolio traded with only the informal approval of a partner. ${ }^{98}$ The defendant brokerage house had also failed to make any subsequent investigation or check of the account, even though the record showed that it was among the most actively traded and had in fact generated more than half of the salesman's commissions. ${ }^{99}$ It is unclear from the court's opinion whether the mere failure to give special treatment to a woman's account constitutes lack of diligent supervision. Such a holding, resting on the assumption that female traders are less knowledgeable than their male counterparts, would seem peculiarly unenlightened. Since the court was also careful to note that the plaintiff was a widow, retired, and depended on the account for her income, ${ }^{100}$ the better conclusion to be drawn is that a brokerage firm must make a reasonable and contimuing inquiry into the financial circumstances, trading experience, and investment objectives of each customer-especially those whose accounts are among the firm's most actively traded.

On the other hand, in Lum's, where a salesinan violated rule 10b5 by leaking inside information, the court found the defendant brokerage firm had satisfied the defense of good faith by pointing to a system of adequate and reasonable supervision. ${ }^{101}$ Lehman Brothers maintamed a "coinpliance department" staffed by competent attorneys who periodically met with the salesmen. ${ }^{102}$ Memoranda apprising salesmen of current developments in securities law were regularly circulated. ${ }^{103} \mathrm{~A}$ book of guidelines and a video tape concerning rule $10 \mathrm{~b}$ 5 problems were distributed to all branch offices. ${ }^{104}$ The court also

96. Id. at 987. For an SEC decision also holding that proper supervision requires inspection of every employee's incoming mail, see Kamen \& Co., SEC Securities Exchange Act Release No. 7965 (Sept. 29, 1966), reprinted in [1966-1967 Transfer Binder] CCH FED. SEC. L. REP. $\| 77,408$.

97. 283 F. Supp. 417 (N.D. Cal. 1968), modified on other grounds, 430 F.2d 1202 (9th Cir. 1970).

98. Id. at $438-39$.

99. Id. at 436,439 .

100. Id. at 439.

101. $365 \mathrm{~F}$. Supp. at 1064-65:

102. Id. at 1064 .

103. Id.

104. Id. 
noted that the guilty salesman was a respected and trusted employee, on whose judgment Lehman could reasonably rely. ${ }^{105}$ While Lehman did not at that time have a rule prohibiting salesmen from contacting the management of corporations whose securities were held by clients, the court did not feel the absence of such a rule negated the good faith defense. ${ }^{106}$

The "objectification" of the good faith defense has conveniently served to make the defense manageable. While good faith is traditionally measured by the defendant's intent, purpose, or motive rather than by his due diligence or care, ${ }^{107}$ it is much easier to screen the adequacy of a broker-dealer's supervisory procedures than it is to probe the corporate mind of Merrill Lynch. But in loosely equating good faith with non-negligent supervision, the courts are suggesting an erroneous standard. Certainly, stringent supervisory procedures are important evidence of an employer's good faith. Bad faith, however, is not the same as mere negligence, but rather requires a showing of scienter or conduct which is intentional or reckless in nature. ${ }^{105}$ Just as negligent conduct is probably not sufficient to establish liability in a private damage action under rule $10 \mathrm{~b}-5,{ }^{100}$ a neghigent failure to supervise should not justify the imposition of liability on a brokerage firm for the acts of its employee when the firm is sued by a private investor. The standard sliould be different from that applied under the NYSE or NASD "diligent supervison" rules or in an administrative proceeding by the SEC. In Kamen \& Co. v. Paul H. Aschkar $\& C o .,{ }^{110}$ the Ninth Circuit did impliedly nrake this distinction, finding

105. Id. at 1065 .

106. The court seemed to be impressed by the fact that no other broker-dealers had "focused" on the problem of employee contacts with management. Id. But see Paine, Webber, Jackson \& Curtis, SEC Securities Exchange Act Release No. 8500 (Jan. 12, 1969), reprinted in [1967-1969 Transfer Binder] CCH FED. SEC. L. REP. II 77,650, rev'd on other grounds sub nom. Klopp v. SEC, 427 F.2d 455 (6th Cir. 1970) (the fact that supervisory procedures are equal to or better than those of other firms of comparable size is not an excuse); F.S. Johns \& Co., SEC Securities Exchange Act Release No. 7972 (Oct. 10, 1966), reprinted in [1966-1967 Transfer Binder] CCH FEd. SEc. L. REP. I 77,410, aff'd sub nom. Winkler v. SEC, 377 F.2d 517 (2d Cir. 1967) and Dlugash v. SEC, 373 F.2d 107 (2d Cir. 1967) (although others may be deficient in providing adequate supervision, that fact cannot excuse the defendant).

107. See 2 BROMBERG $\$ 8.4(504)$.

108. See Gould v. American Hawaiian S.S. Co., 351 F. Supp. 853, 860 n.7 (D. Del. 1972). The difference between the scienter requirement in a 10b-5 action and the good faith defense under section 20(a) is merely a shift in the burden of proof from the plaintiff to the defendant. See id. at 858 n.4. See also Gordon v. Burr, 366 F. Supp. 156, 168 n.11 (S.D.N.Y. 1973).

109. See Bucklo, Scienter and Rule I0b-5, 67 Nw. U.L. Rev. 562-63 (1972).

110. 382 F.2d 689 (9th Cir. 1967), cert. dismissed, 393 U.S. 801 (1968). 
no bad faith by the defendant broker-dealer in its selection and supervision of employees ${ }^{111}$ even though, on the same set of facts, the SEC had temporarily suspended the defendant from the national securities exchanges and the NASD on the ground there was negligence under the standards of the diligent supervision rules. ${ }^{112}$ But other courts, carelessly speaking in terms of neghigence rather than of a reckless or willful failure to supervise employees, could easily, in a laudable attempt to objectify the good faith standard, oversimplify the defense to the point where even sliglit negligence nullifies the broker-dealer's good faith. ${ }^{113}$

\section{Conclusion}

Two different theories of broker-dealer liability for the federal securities violations of salesmen have been discussed herein: "respondeat superior" or agency liability, and liability under the controlling persons sections of the securities acts. Once the existence of an agency relationship has been established, the employer's liability is absolute. Since most suits involve misrepresentations by employee-salesmen clearly acting within the scope of their employment, the "lack of an agency" defense is relatively unimportant. The controlling persons sections, however, while ensnaring more than merely the agents of the brokerage firm, provide the broker-dealer with valuable statutory defenses. Therefore, imjured investors will generally prefer to utilize an agency theory of liability.

Several courts have allowed respondeat superior as a method of imposing secondary liability on brokerage firms for their salesmen's violations of the federal securities acts. However, the better reasoning appears to be that the controlling persons provisions of these acts have excluded agency liability for sucli violations. As a matter of policy, if a plaintiff has elected to sue for violation of one of the federal antifraud provisions, he slould not then be able to impose absolute liability on the brokerage firm in blind disregard of the broker's defenses allowed under the controlling persons sections. Moreover, the

111. Id. at 697.

112. See Kamen \& Co., SEC Securities Exchange Act Release No. 7965 (Sept. 29, 1966), reprinted in [1966-1967 Transfer Binder] CCH FED. SEC. L. REP. If 77,408.

113. Under this standard, the reasoning in First Securities should not be followed, since a brokerage firm which merely omits to inspect its president's mail can hardly be deemed to be acting in bad faith. On the other hand, Hecht was probably correctly decided even under a bad faith standard in view of the fact the wrongdoing salesman was earning half of his commissions from the plaintiff's account and no investigation of the account was ever undertaken. 
controlling persons provisions, defining "control" specifically in terms of agency, would, on their face, seem to exclude liability based on common law agency principles.

Given the exclusivity of the controlling persons provisions in federal securities suits, the most important remaining issue is the nature of the statutory defenses. Although neghigence is probably sufficient misconduct to justify liability under the Securities Act, a broker-dealer should not be held hable under the 1934 Act if it sustains the burden of good faith by showing it was not reckless in the supervision of employees. While many courts appear to impose a higher burden, requiring the broker-dealer to show no negligence in its supervisory procedures, such a construction is an unwarranted interpretation of the good faith defense. The courts' understandable concern that a subjective standard might be difficult to apply should not be permitted to obscure the clear statutory language. 